\title{
Parents Views of Students on Islamic Education Learning at Home During Covid-19 Pandemic Period in Kecamatan Medan Marelan
}

\author{
Abdillah $^{1}$, Masganti ${ }^{2}$, Saddam Husein Siregar ${ }^{3}$ \\ Universitas Islam Negeri Sumatera Utara, Indonesia \\ abdillah@uinsu.ac.id
}

\begin{abstract}
This study took 4 Islamic Religious Education teachers and 3 parents of students to convey their views on learning Islamic Religious Education at home during this pandemic. This study used qualitative research methods. It can be concluded in this study that learning Islamic Religious Education at home is considered less effective. Parents and teachers agree that studying at home is less effective, where teachers have difficulty evaluating and cannot understand students' abilities. Parents have limited ability and time to accompany learning. And students are not disciplined in learning so they play more than learn. The solution offered in this study is for parents and teachers to work together by opening a meeting via WhatsApp group or video conference to discuss what teachers and parents hope to achieve with the school as well, of course. As well as for local governments that are sustainable with the Education Office and Schools to work together to implement health protocols for students and teachers so that learning can be carried out face-to-face by reducing the number of students in the class and maintaining distance or making learning shifts. Even though with a short time getting the material, this is even more beneficial than studying at home As well as for local governments that are sustainable with the Education Office and Schools to work together to implement health protocols for students and teachers so that learning can be carried out face-to-face by reducing the number of students in the class and maintaining distance or making learning shifts.
\end{abstract}

Keywords

parents views, learning islamic religious education at home; covid-19 pandemic period

\section{Introduction}

Education as an important thing cannot be ignored because education aims to equip students to prepare for their future. Therefore, a meaningful learning process determines the achievement of quality education. Education is needed by each individual. For that students must receive adequate guidance, opportunities and encouragement in learning and learning the things they need in their future lives. Education is the basic need of every human being to ensure his survival in order to be more dignified (Djamarah \& Zain; 2002: 27).

Islamic Religious Education in schools aims to increase students' understanding, appreciation, belief and practice of Islam so that they become Muslims who believe and fear Allat Swt and have noble morals in their personal, social, national and state life and to continue their education at a different level higher. The expected goals in Islamic Religious Education are (1) to instill the values of faith and devotion to God. (2) instilling 
cultural values in general, (3) developing personality, (4) developing sense of sensitivity, (5) developing talents, (6) developing interest in learning, (7) increasing noble character according to religion and belief .

The government implements physical distancing and asks children to study from home amid the corona pandemic outbreak. This step was taken to break the chain of spreading the corona virus in Indonesia. However, the current implementation of learning from home often leaves problems. Many parents are troubled because of the many tasks given by the school. There is a misinterpretation of students' parents and even teachers regarding "Studying at home during the corona pandemic. The school seems to only move the learning process from class to home. Materials and assignments are given online or online, through various platforms provided by the government and the private sector.

During the current Covid-19 pandemic, Islamic Religious Education and other subjects are carried out online / online or if students find it difficult to learn online / online, learning is carried out at home accompanied by parents. There have been many changes in the learning process since the Minister of Education and Culture's decision in March 2020 so that it affects the implementation of learning in students. So that learning does not only involve the teacher but the role of parents. During this pandemic, all circumstances change where learning changes. In Islam too, there is a hadith that discusses an epidemic, namely:

The Messenger of Allah -peace and prayer of Allah be upon him- said: "Tha'un (epidemic of infectious diseases) is a warning from Allah Subhanahu Wa Ta'ala to test His servants from among humans. So when you hear that a disease is spreading in a country, do not enter that country. And if the plague breaks out in the land where you are, don't run away from it either " (Narrated by Bukhari and Muslim from Usamah bin Zaid).

Journal by Abd. Rouf (2015: 10) states that in reality there are still many Islamic Religious Education in schools that have not met expectations. For example, if a teacher provides Islamic religious education to students, of course what is desired is that students not only understand but can also carry out Islamic teaching practices that are essential to themselves and those of a social nature. Because in Islamic Religious Education not only pay attention to cognitive aspects, but also the attitudes and skills of students. It can be concluded that studying at school alone has problems, how about defending at home. At home who play the role is family.

One of the journals that discusses PAI students during the Covid 19 pandemic is a journal by Ahmad Jaelani (2020) where the Covid-19 Outbreak has an impact on Islamic Education learning in schools. This situation forces the world of education to carry out an online learning process. The results of the study prove that the use of online media during the Covid-19 pandemic has caused various responses and impacts and changes in the learning system that can affect the teaching and learning process and the level of development of students in responding to the material presented. The impact of the Covid19 Pandemic on the educational aspect is that it requires teaching and learning activities to continue even though students are at home. The solution, educators are required to design learning media as an innovation by utilizing online media.

Education is an obligation of every human being that must be pursued to hold responsibilities and try to produce progress in knowledge and experience for the lives of every individual (Astuti et al 2019). The family has a very big role in teaching, guiding, determining behavior, and forming a perspective on the values that apply in society. The family is like giving the values that are needed by the child through an appropriate communication pattern so that communication goes well, harmonious relationships are created, and the messages and values to be conveyed can be accepted and practiced properly (Batubara et al, 2019). Thariq (2018) stated that the family is the main pillar of 
life, especially for young generation. The family is the first educator and guard leader to realize human resources. For that the total support of the family is able to give birth as if a miracle in their life.

Education in the family has a strategic role and greatly determines the achievement of the quality of human resources. In the implementation of family education, it does not only play a role as implementer that is utin and natural, but also acts as a manager who is responsible for laying the foundation and giving weight and direction and patterns of children's life. Parents who apply very strict, loose and flexible or flexible family education have different impacts on the personal formation of the child. In daily life, parents expect their children to follow in their own footsteps, some are free and some are indifferent. Every parent in educating their children has different ways (Rusydi and Abdillah: 2018).

According to the research journal Selfia (2018: 201), the role of parents has a very big influence on the success of students in learning. The level of education of parents, the size of their income, sufficient or inadequate attention and guidance from parents, whether the parents are harmonious or not, the relationship between parents and children, whether the situation at home is calm or not, all of these affect the achievement of learning outcomes learners.

According to Abdillah (2012), parents are "first, primary and natural educators". Parents are the first people he sees as all-knowing. Children rely all their hopes on their parents. When he experienced any difficulty, he always asked his parents for help, when he was talking to his peers, the children always made their parents proud.

In order to explore children's potential, an active role of parents is needed. Parents act as role models who understand children's development and also provide care and education. Education should be the most important and main means for children to develop their potential. Parents must try to be able to send their children to the highest level of education is one way so that children can be financially independent later.

But nowadays, with the conditions of studying at home or online, there are many incidents of parents complaining about assignments and complaining about learning that drains the mind and energy of parents because learning Islamic Religious Education cannot be carried out directly. Like many things we find on social media, a lot of parents complain about learning at home, including on Islamic Religious Education. Moreover, the average parent is busy working both or the head of the family. So that it will have a huge effect on the learning at home that is carried out.

Then the problem of learning Islamic Religious Education also exists in students where the environment in which they are in has experienced a lot of moral decadence caused by weak control and self-awareness of religious values. The problem is also with the provision of learning facilities and infrastructure for Islamic Religious Education, this is closely related to learning at home which is only equipped improperly.

Several parents of students in Marelan were interviewed and complained that the teacher did not provide teaching materials but immediately gave assignments without knowing what chapter the book was in. Then the limitations of students who have textbooks are also an obstacle in learning Islamic Religious Education at home so that many parents do not ready to help their children in doing assignments at home given by the teacher. Parents also complained about their limited ability to help their children do assignments so that learning materials were needed before doing assignments.

Based on the background of the problem above, where various problems regarding the implementation of Islamic Religious Education learning at home have been described, the focus of the problem in this study is the views of parents of students towards learning Islamic Religious Education at home during the Covid-19 pandemic in Medan Marelan District. 


\section{Research Methods}

This research was conducted in Medan Marelan District. Precisely for parents who have children who are already enrolled in SD or SMP. In general, SD and SMP have Islamic Religious Education learning, during the Covid-19 pandemic that all students learn online / online from home. This study took 4 Islamic Religious Education teachers and 3 parents of students to convey their views on learning Islamic Religious Education at home during this pandemic.

This research approach is carried out qualitatively, meaning that the research procedure produces descriptive data in the form of words from people or observed behavior (Bogdan \& Taylor in Moleong, 2010: 4). This approach is directed at the cultural background and individuals who are used as sources / informants of this research holistically (intact). Basically, according to some experts there are several methods that have developed in qualitative research, including; case studies, phenomenology, grounded theory, ethnometodology, ethnography, biography, clinical research and historical social sciences (Agus Salim 2001: 89).

This qualitative research design is a case study, a case study is an approach to studying, explaining, or interpreting a case in its natural context without any intervention from outside parties (Agus Salim, 2001: 93). A case study is also an in-depth study of social units which results in a complete and well-organized picture of the units.

According to Sugiyono (2010: 148) a research instrument is a tool used to measure observed natural and social phenomena. The data collection techniques used in this research were observation, interview and documentation. Therefore, this study was assisted by instruments of observation guidelines, interview guides, recording devices, cameras and writing instruments. The data analysis process begins by examining all available data from various sources, namely from interviews and observations that have been written in field notes. After reading, studying, and analyzing, the next step is to reduce the data by doing an abstraction. After completing this stage, begin at the data interpretation stage in processing interim results into substantive theory (Moleong, 2004: 247).

\section{Results and Discussion}

\subsection{The views of parents of students on learning Islamic Religious Education at home during the Covid-19 Pandemic in Medan Marelan District}

According to information from the resource person, there is learning at home that has limited Islamic religious knowledge so that sometimes it cannot help the child in doing Islamic Education learning questions. Feeling unclear because the teacher's explanation is short and the material is not broad because maybe the teacher also maximizes the time when sending material in the form of video or voice notes.

The results of interviews from other sources said that according to parents, learning did not vary, the duration of learning was also unclear. Then the child is not disciplined and the ability of parents to assist children in learning is limited. According to the informants, learning Islamic religious education is considered less effective. Suggestions to the teachers do not just give training / theory too often, but give practical assignments by requiring children to pray 5 times a day and others so that more visible changes in the child's personality are better. As well as the limitations of parents in assisting children in learning are the main things in this online learning. 
The results of interviews with students' parents concluded that the three informants gave their responses that learning Islamic Religious Education at home was considered less effective, and had more shortcomings than its advantages. Parents complained about data package problems, then limited time to assist, the limited ability of parents to accompany and children who are not disciplined at home so it is very troublesome for parents. Moreover, children do not obey when their parents give orders. Then the parents' suggestion to the teacher is to further clarify the material and not only give assignments theoretically only exercises, it is better for practical applications at home because they see children who are less disciplined in doing their assignments.

The results of observations about the views of students 'parents on learning Islamic Religious Education at home during the Covid-19 Pandemic in Medan Marelan District are: 1) direct observation at the home of the parents of students to check the truth of student learning, 2) the condition of the students' parents at home who are either workers or who have time at home. 3) The learning conditions of some students are difficult because they do not have cellphones and some have complete facilities. 4) students study irregularly at home, because they have more free time.

\subsection{Implementation of Islamic Religious Education learning at home During the Covid-19 Pandemic}

The conclusion from the informants was that it was difficult to coordinate and see the progress of students because sometimes parents were doing the assignments given by the teacher, as well as the difficulty of evaluating students. As well as the many negative assumptions on teachers for carrying out Islamic religious education at home.

The conclusion from the informants is that in the implementation of learning Islamic Religious Education at home, there are many parents who do not have Android phones and students have difficulty because the material is distributed via WhatsApp, video call / conference, and ship system. And many parents who suggest face to face and it can be concluded that learning is not effective.

Information from the informants said that there are indeed a lot of obstacles in studying at home at this time. Where the teacher concludes that learning is ineffective, and there are lots of negative assumptions for the teacher, especially the issue of incentives and the way of assessment for teachers is very difficult because they do not know students' abilities directly and this is very difficult in assessment. And there are also many complaints from parents, especially problems with data packages and cellphone use

The informant said that studying Islamic Religious Education at home at this time had the most obstacles compared to its advantages. Where is the problem of children who do not have cellphones, the difficulty of providing learning media to students and teaching materials, then the difficulty of evaluating students and parents who have not been able to work with teachers because this teaching task is delegated to the teacher.

The results of interviews from teacher respondents stated that the teacher always provides teaching materials or learning media that will be distributed via WhatsApp, video conference or google classroom where all students learn through the application. Unfortunately the teacher considered that learning at home on Islamic Religious Education was considered ineffective. Moreover, not all children have a smart phone and parents complain a lot about this and the difficulty of controlling learning movements at home. Hence the hope of parents that students learn face-to-face immediately so that they do not have difficulty managing children's work and assignments. Although online media is considered quite effective in learning by experts, the reality in the field proves that the role of teachers in teaching and the learning process cannot be replaced by technology. 
In this study, the researchers offered a solution so that local governments, who are sustainable with the Education Office and Schools, work together to implement health protocols for students and teachers so that learning can be carried out face-to-face by reducing the number of students in the class and maintaining distance or making learning shifts. Even though with a short time getting the material, this is even more beneficial than studying at home. Then interviews were also conducted with students where it was the students who were affected by learning Islamic Religious Education at home only.

The results of interviews with students' parents concluded that the three informants gave their responses that learning Islamic Religious Education at home was considered less effective, and had more shortcomings than its advantages. Parents complained about data package problems, then limited time to assist, the limited ability of parents to accompany and children who are not disciplined at home so it is very troublesome for parents. Moreover, children do not obey when their parents give orders. Then the parents' suggestion to the teacher is to further clarify the material and not only give assignments theoretically only exercises, it is better for practical applications at home because they see children who are less disciplined in doing their assignments.

The results of observations about the views of students 'parents on learning Islamic Religious Education at home during the Covid-19 Pandemic in Medan Marelan District are: 1) direct observation at the home of the parents of students to check the truth of student learning, 2) the condition of the students' parents at home who are either workers or who have time at home. 3) The learning conditions of some students are difficult because they do not have cellphones and some have complete facilities. 4) students study irregularly at home, because they have more free time. Then for the views of parents of students on learning Islamic Religious Education at home on the Covid-19 Pandemic in Medan Marelan District, it is proven by photo document evidence with parents and students.

From the three data collection techniques above, a conclusion is drawn for the views of students' parents on learning Islamic Religious Education at home during the Covid-19 Pandemic In Medan Marelan District, Islamic Religious Education at home is considered less effective, and has more shortcomings than its advantages. Parents complained about data package problems, then limited time to assist, the limited ability of parents to accompany and children who are not disciplined at home so it is very troublesome for parents. Moreover, children do not obey when their parents give orders. From the observation data it also states that learning Islamic Religious Education at home is considered less effective, because the observational data concluded that children's time was more free than learning, thus reducing student motivation. plus student documentation data obtained, that students learn if ordered by parents only. Incidentally, when researchers visited students and their parents' homes, students immediately rushed to learn and reports from parents playing more than learning.

\section{Conclusion}

It can be concluded in this study that learning Islamic Religious Education at home is considered less effective. Parents and teachers agree that studying at home is less effective, where teachers have difficulty evaluating and cannot understand students' abilities. Parents have limited ability and time to accompany learning. And students are not disciplined in learning so they play more than learn. The solution offered in this study is for parents and teachers to work together by opening a meeting via WhatsApp group or video conference to discuss what teachers and parents hope to achieve with the school as well, of course. As well as for local governments that are sustainable with the Education Office and Schools to 
work together to implement health protocols for students and teachers so that learning can be carried out face-to-face by reducing the number of students in the class and maintaining distance or making learning shifts. Even though with a short time getting the material, this is even more beneficial than studying at home.

\section{References}

Abdillah. (2012). Relevansi Kewibawaan dan Kewiyataan dengan hasil belajar Siswa. Nadwa: Jurnal Pendidikan Islam. https://journal.walisongo.ac.id/index.php/Nadwa/article/view/593. DOI: 10.21580 / nw.2012.6.2.593.

Abd. Rouf. (2015) Portrait of Islamic Religious Education in Public Schools. Journal of Islamic Religious Education Volume 03, Number 01, May 2015 pp. 191-206.

Ahmad Jaelani. (2020). The Use of Online Media in the Process of Pai Dimasapandemi Covid-19 Teaching and Learning Activities (Literature Study and Online Observation). 12 Ika Journal vol 8 no. 1 June 2020: PGSD UNARS Alumni Association. P-ISSN: 2338-3860. Vol. 8 No. 1, June 2020 E-ISSN: 2656-4459.

Ali Ashraf. (1997). New Horizon of Islamic Education. Jakarta: Pustaka Firdaus.

Astuti, R.W., et al. (2019). Character Education Values in Animation Movie of Nussa and Rarra. Budapest International Research and Critics Institute-Journal (BIRCI-Journal). P. 215-219.

Batubara, M.U., et al. (2019). Islamic Communication Pattern of Judges in Dealing Conflict of Muslim Families in the Religious Court Medan. Budapest International Research and Critics Institute-Journal (BIRCI-Journal). P. 373-386.

Djamarah, Syaiful Bahri, (2005). Teachers and Students in Educational Interaction. Jakarta: Renila Cipta.

Moleong, Lexy J. 2010. Qualitative Research Methodology. Bandung: Youth Rosdakarya.

Mulyasa, E. 2010. Becoming a Professional Teacher (Creating Creative and Fun Learning). Bandung Rosda. The ninth print.

Rusydi, A. dan Abdillah, (2018). Pembelajaran Terpadu: Karakteristik, Landasan, Fungsi, Prinsip dan Model. http://repository.uinsu.ac.id/3585/1/6.\%20BUKU\%20PEMBELAJARAN\%20TERP ADU.pdf.

Sugiyono. 2010. Educational Research Methods with Quantitative Approaches, Qualitative, and R \& D. Bandung: Alfabeta.

Thariq, M. (2018). Interpersonal Communication Role For Self- Concept Of Children And Families. Budapest International Research and Critics Institute-Journal (BIRCIJournal). P. 182-195. 